\title{
Testing for Motivation to Engage in Improvements - A Conceptual Framework and an Initial Empirical Test
}

\begin{abstract}
This paper aims to develop a conceptual framework for testing the motivation to engage in improvement work. The framework is based on Ajzen's Theory of Planned Behavior (TPB), that we suggest can be used to facilitate implementation of improvement programs. By using the model and probing intentions, attitudes, norms and perceived ability related to improvement work, we believe hindrances for implementation of improvement programs will be exposed. When operationalizing the framework we developed a survey instrument based on TPB and then made an initial empirical test by distributing it to 124 employees (response rate $67 \%$ ) of three manufacturing SMEs. Factor analysis and regression were used to analyze the survey and followup interviews with employees and managers were used to validate the results. This initial test of the instrument showed that it has sound measurement properties, indicated by clear factor structure and good internal consistency. Interview data also validated that the instrument was able to capture important aspects related to implementation of improvement work. Based on the result, we conclude that TPB may be useful for guiding management actions. However, since our study only draws on a limited empirical sample, future research is needed to test the contextual validity. Keywords: Improvement programs, Lean, Employee engagement, Management commitment.
\end{abstract}




\section{Testing for Motivation to Engage in Improvement Work}

Improvement work has been presented under many names, such as Total Quality Management (TQM), Lean Manufacturing and Six Sigma to mention a few. Following an initial debate, the research community are now coalescing into an agreement that improvement programs, when thoroughly implemented are effective in increasing organizational performance (e.g., Powell, 1995; Lemak \& Reed, 1997; Samson \& Terziovski, 1999; Hendricks \& Singhal, 2001; Kaynak, 2003; Shah \& Ward, 2003; Nair, 2006; Prajogo \& Sohal, 2006; Sila, 2007; Abdullah, Uli \& Tari, 2009).

Many studies have found positive correlations between management of employees and successful implementation of some quality management concepts such as Total Quality Management (Flynn, Shroeder \& Sakakibara, 1995; Ho, Duffy \& Shih, 1999; Kaynak, 2003, Yeung, Cheng \& Lai, 2006) and between the attitudes of employees and business results, including profits (Flynn et al., 1995; Harter, Schmidt \& Hayes, 2002). Others have found positive correlation between implementation results and employee involvement (Dow, Samson \& Ford, 1999; Das, Handfield, Calantone \& Ghosh, 2000; Kaynak, 2003), between employee involvement and job performance (Harrison, Newman \& Roth, 2006) and between employee empowerment and implementation results (Powell, 1995, Samson \& Terziovski, 1999). From this, we can conclude that if an implementation of an improvement program is to be successful, employee engagement and management of employee relations are important.

However, work to reduce waste - with the aim to spend less time on activities that do not add customer value - may also reduce the employee's room for action and their ability to handle a potentially stressful working climate. Increases in stress, injuries as well as sick-leaves, and an 
overburdened staff often seem to be by-products of the more efficient working environment following improvement programs (Landsbergis, Cahill \& Schnall, 1999; Korunka, Scharitzer \& Sainfort, 2003), and the resulting work organizations have sometimes been described as anorectic (Radnor \& Boaden, 2004). For this reason, improvement programs, for instance TQM, have been stated to be merely a repackaged traditional capitalistic management model stemming from Adam Smith and Frederick Winslow Taylor (Johansson \& Abrahamsson, 2009). It is not certain that what is good for the company is also good for the worker. One cannot demand true involvement of the staff into a program that may make the working environment more stressful, reduce work content and lead to layoffs. If the employees perceive that the improvement program will lead to negative personal outcomes, the program will likely fail. While we can conclude that research have found that improvement programs lead to positive effects for the firms, and firms need to be competitive and efficient to sustain and keep employees, it is not certain that the shortterm effects for the employees are as positive. The demands of the staff therefore need to be balanced during the implementation of improvement programs and the management may have to monitor the engagement of the staff during the implementation.

In this paper, we explore if and how the employee motivation to engage in improvement work may be measured using the framework "Theory of Planned Behavior" (TPB) (Ajzen, 1991). Considerable research attention has been directed to connecting attitudes to behavior, and many models have been produced. The Theory of Reasoned Action (Ajzen \& Fishbein, 1980) and the Theory of Planned Behavior (TPB) (Ajzen, 1991) are probably the most researched of these; the difference between the models is that the TPB model includes an element relating to the person's belief of behavioral control over the action. In this paper, we wish to lay a foundation for using TPB as an instrument to measure intentions to participate in improvement programs based on 
employee attitudes, perceived organizational norms and perceived behavioral control. To link intentions to action is thus beyond the scope of this study.

The rest of the paper is organized as follows. First, there is a section introducing the Theory of Planned Behavior in general terms followed by a section on how it can be linked to improvement work. Then, we introduce a case study of improvement work based on the lean philosophy. The method we have employed is thereafter presented and then the results from the study are put forward. Finally, we discuss the results and offer conclusions.

\section{The Theory of Planned Behavior and Improvement Work}

The introduction of any improvement program could be considered a cultural change and theories such as Ajzen's Theory of Planned Behavior could therefore prove useful for understanding outcomes of the implementation when engaged in improvement work. In their early work, Fishbein and Ajzen (1974) showed through an empirical investigation that attitudes towards a certain object are not by itself enough to explain the intentions of individuals to perform a required action. People may thus be positive towards quality improvement work in general, but may have no intentions to engage in such activities. Since the success of improvement work is dependent of the engagement and participation of all those affected by the actions taken, instruments based on the theory for planned behavior may have better explanatory power than instruments only measuring attitudes.

Fishbein and Ajzen's Theory for Reasoned Action (Ajzen and Fishbein, 1980) and Ajzen's Theory for Planned Behavior (TPB) (Ajzen 1991) have received support (e.g., Conner, 2000) regarding their ability to explain behavior of persons. The TPB model postulates that a person's intentions to perform a behavior is positively correlated with the behavior, and that the intention is governed by three determinants - the personal attitude towards a behavior, the 
perceived social norms of the expected behavior, and the perceived personal control over the behavior that the individual has. Thus, according to TPB, a person will base his or her choice to behave on three main factors: 1) the attitude the person has for the behavior, 2) the belief held by the person about other important persons' attitude about the behavior (the subjective norm) and 3) the perceived ability the person has to perform the behavior. In the model intentions will mediate between the three factors and actual behavior, and suggest that perceived behavioral control (ability) can have a direct link to behavior, see Figure 1.

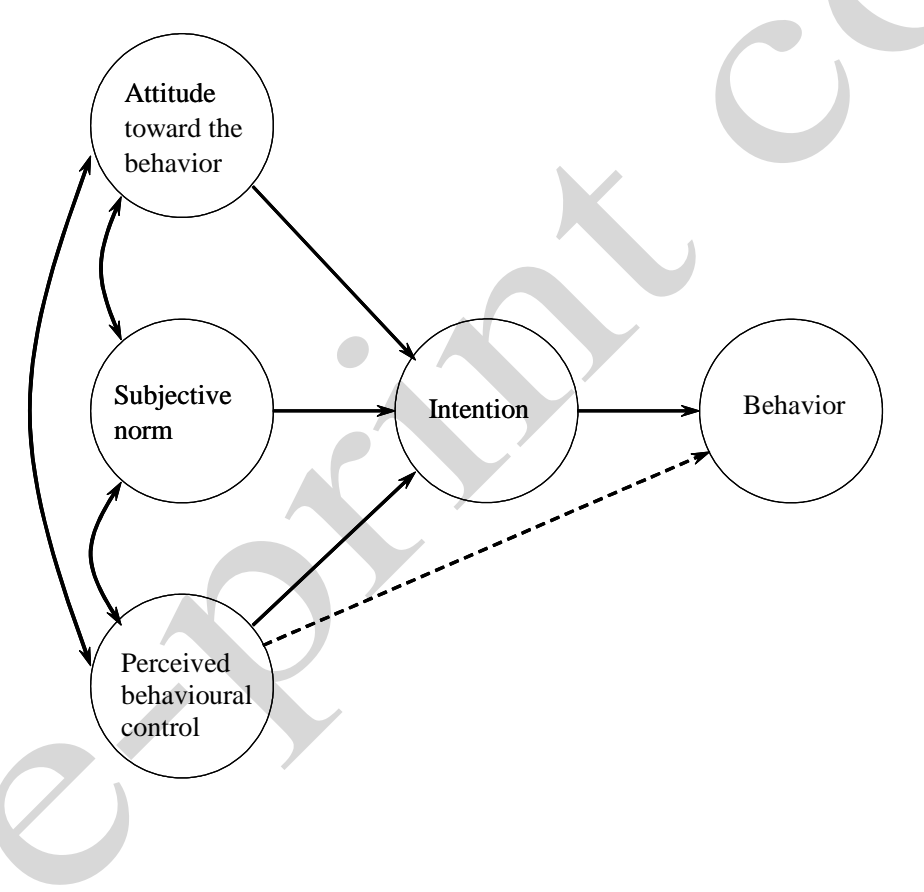

Figure 1. Ajzen's Theory of Planned Behavior (Ajzen, 1991).

\section{TPB in Studies of Motivation to Engage in Improvements}

The TPB model has often been used in a range of health related studies (e.g., smoking and condom use), in marketing predicting consumer behavior, in entrepreneurship to predict who are likely to start a firm. While TPB has been used extensively in other fields, it is rarely used in studies of implementation of improvement programs. In an organizational context, Dawkins and 
Frass (2005) studied union workers' decision to engage in an employee improvement program. The authors found TPB potentially effective in predicting behavioral outcomes, but concluded that more studies in employee involvement were needed (ibid.). Jimmieson, Peach and White (2008) studied employee intentions to support organizational change using TPB. They found strong correlations between the actual behavior and (1) positive attitudes of employees versus an organizational change, (2) perceived pressure from others to complete required actions, and (3) a feeling of being in control to perform the behavior (ibid.). People who were positive towards changes and had intentions to engage and felt they had means to affect the outcome were more likely to carry out tasks supporting the change (Jimmieson, et al., 2008).

However, although organizational change and employee involvement are important aspects in any improvement program implementation, we have not found examples of studies of instruments to measure employee engagement in the quality management literature. This paper therefore aims to conceptualize and also briefly demonstrate the TPB model and possible outcomes of a TPB study using a case study.

\section{The Case: Lean Six Sigma SME Network}

In March 2008, the managers and owners of three small Swedish manufacturing companies in a small town in the north of Sweden decided to engage more in improvement work to remain competitive. Inspired by the Six Sigma program, they jointly agreed to hire a full-time improvement consultant (often referred to as "Black Belt"). The shared consultant was to work directly with improvements and to lead improvement teams within the companies. Their company sizes, products, and markets differed, but they had the advantage of being located closely to each other, and they were all manufacturing companies in the construction business or with construction-related products. The largest company, Alfa, a manufacturer of prefabricated 
wooden apartment buildings, had a workforce of 130 people and an annual turnover of $30 \mathrm{M} €$, and was a family enterprise. The other companies, Beta and Gamma were smaller. Beta, a door manufacturer and to a small part a subcontractor to Alfa employed eighteen people, had a turnover of just below $3 \mathrm{M} €$. Beta was co-owned by the CEO and the production manager. The last company, Gamma, was owned by the CEO, employed 17 persons, had a turnover of approximately $5 \mathrm{M} €$ and specialized in manufacturing insulated compartments for construction purposes.

We interviewed managers in the three companies and the improvement consultant three months into the project, and the results from these interviews showed that the project was soon redirected from Six Sigma towards lean methods. 5S was a common starting ground in all companies and it was applied to one workgroup at a time in each company. The idea was that the frontrunner group would inspire the remaining groups to start their $5 \mathrm{~S}$ activities. The improvement activities also differed and took customized forms, depending on the companies' special needs. Improvement suggestion boards and quality circles were started in two companies. (Reference withheld to guarantee the anonymity of reviewing process)

In Gamma, the improvement consultant worked extensively with improving the flow of the production plant. In Beta, the flow and layout in one of the major production steps were redesigned. The work of the Black Belt in Alfa included initiating standardized work procedures in the production department.

The interviews three months after the project start showed that the improvement work was seen as positive by all top managers as well as by the Black Belt. The managers had expected more improvement suggestions stemming from the networking and that the consultant would share more insights sprung from the other companies, but thought that networking effects could 
improve when the companies had worked longer together. During these interviews, the consultant and the managers themselves felt that visible management commitment and support for the improvement activities and the consultant could improve, and that the improvement work was impaired by their lacking support. (Reference withheld to guarantee the anonymity of reviewing process).

This result was discussed during a project meeting, and the involvement and support of management was put high on the agenda on the following project meetings. Six months after the start, the consultant thought that he received more attention both from management and from the employees in all companies. Management support was, however, still an issue in company B where the CEO was not regularly on the production site and expressed doubts about the effort, since business was slowing. Due to the reduced sales, they had had to reduce staffing, and the improvement work had at times intervened with the regular production when the production was more trimmed.

\section{Methods and Design for Data Collection and Analysis}

Nine months after the initiation of the project, a survey was performed as a follow up of the first set of interviews. The survey was directed to shop floor workers, middle managers, as well as upper management. The questionnaire was based on the Theory of Planned Behavior (see Appendix for the questions used), and included a section for background information to provide control variables for the study. Questions were developed to probe improvement work and contained questions about employee attitudes, perception about management support (both supervisor/manager and top management), and ability to perform the tasks for improvement work. The intentions of the employee to be involved in the improvement work in the future, and intentions to improving their personal work situation were the dependent variables, see 
Appendix. The survey was anonymous, and the Black Belt handed out the questionnaires to the employees during a break. The survey was returned by 83 of 124 possible respondents, giving a response rate of $67 \%$.

The survey results were analyzed using exploratory factor analysis (Principal Component Analysis with oblique factor rotation, $\operatorname{SPSS} \AA$ 18), where all variables were found to be unidimensional and have Cronbach's alpha between .70 and .90. (See Table 1 below for details), which indicate good reliability. The exception is attitudes to improvement work $(\alpha=.59)$, but since this attitude variable is a two-item scale, a low alpha is not surprising. For item wordings and item factor loadings, see Appendix. All items were measured on a seven-point Likert scale anchored at "completely disagree" and "completely agree".

We used several controls that may explain intensions to behavior. First, experience with improvement work may be a powerful explanatory variable since earlier experience normally provides tools to handle new similar situations. We therefore controlled for three types of experience: 1) direct experience from the present project, 2) experience from earlier improvement work in the same firm, and 3) experience from improvement work in earlier employments. Second, education may also influence the intention to work with improvements, where those with higher education could be expected to be more positive and have a higher ability to learn new tasks. Third, age may also explain intentions to change, where younger age normally is linked to a stronger intention to change. Finally, we controlled for workplace to test firm level differences in intentions to work with improvements. Since we used this company control variable it is possible to merge all data into one analysis.

The data were analyzed using hierarchical regression analysis where controls were entered in the first step and then independents (i.e., attitudes, norms, and abilities) were entered in 
the second. Altogether, 10 variables were used, which is at the upper limit in our study. We find 10 variables reasonable since this is an exploratory study, but generalizations must be inferred cautiously.

As a follow-up to the survey, key personnel identified from the survey were interviewed during a second round of interviews 15 months after the project start. We also studied the improvement work by participating in project meetings and having regular discussions with the Black Belt in an action research approach. This information helped us with interpretations of the survey data.

\section{Key Findings of the Survey and Interviews}

Most bivariate correlations between the variables were moderate to high (see Table 1). The response averages were also above the scale center, which indicate that the respondents in general had positive attitudes, perceived strong management support, and felt rather competent in their improvement tasks. Notably, norms were often ranked lowest, indicating that the actions of management was not considered to express an as high commitment to the improvement work as the employees' own attitudes. The lower perceived management commitment was also brought forward in the follow-up interviews, where the interviewees considered management sometimes too invisible and, when in conflict, prioritized production rates rather than improvement work. 
Table 1. Correlation matrix and details for variables

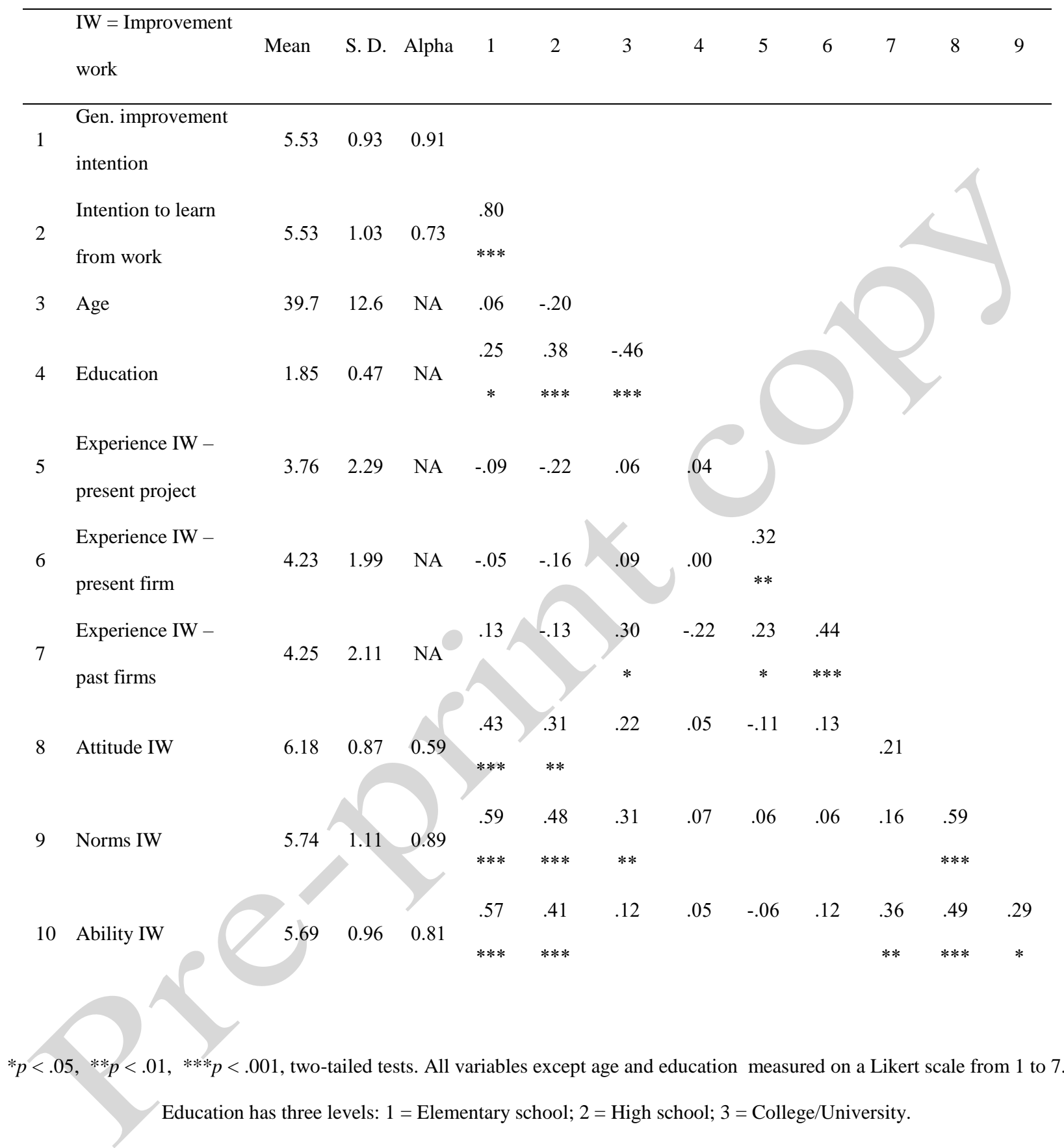




\section{Table 2 - Results of hierarchical regression analysis}

\begin{tabular}{|c|c|c|c|c|}
\hline IW = Improvement work & General & $\begin{array}{l}\text { orovement } \\
\text { tion }\end{array}$ & $\begin{array}{r}\text { Inten } \\
\mathrm{fr}\end{array}$ & $\begin{array}{l}\text { n to learn } \\
\text { work }\end{array}$ \\
\hline Dummy firm 1 & $-.40^{* * *}$ & $-.22 *$ & $-.41 * * *$ & $-.24 *$ \\
\hline Dummy firm 2 & -.05 & -.09 & -.13 & -.16 \\
\hline Age & .08 & -.05 & -.12 & $-.24 * *$ \\
\hline Education & $.35 * * *$ & $.19 * *$ & $.34 * * *$ & $.20 * *$ \\
\hline Experience IW - present project & $-.27 * *$ & -.14 & $-.32 * * *$ & $-.22 * *$ \\
\hline Experience IW - present firm & -.14 & -.09 & -.12 & -.07 \\
\hline Experience IW - past firms & $.29 * *$ & .05 & .01 & -.11 \\
\hline Attitude IW & & -.10 & & -.14 \\
\hline Norms IW & & & & $.47 * * *$ \\
\hline Ability IW & & $.45^{* * *}$ & & $.39 * * *$ \\
\hline F-ratio & 3,61 & 1.0 & 4,17 & 9,07 \\
\hline R square & ,252 &, 582 & 280 &, 557 \\
\hline R square adj &, 182 &, 524 & ,213 & ,496 \\
\hline Significance & ,002 & $<, 001$ & 001 & $<, 001$ \\
\hline $\mathrm{R}^{2}$ Change & & ,330 & & ,277 \\
\hline $\mathrm{F}\left(\mathrm{R}^{2}\right.$ Change $)$ & & 18,9 & & 15,0 \\
\hline Sign $\left(\mathrm{R}^{2}\right.$ Change $)$ & & $<, 001$ & & $<, 001$ \\
\hline
\end{tabular}


Turning to the regression results (see Table 2), we can see that the control variables explain much of the total variation by themselves, but that the model is significantly improved when the independents are included. For the first model (explaining general improvement intentions), almost $60 \%$ of the variance is explained and the increase in explanation is $33 \%$. The second model expressing intentions to learn shows similar patterns, but explains slightly less of the variation. Two variables are strongly significant and account for similar effects in both models: the norms about the improvement work expressed by management support $(\beta=.45-.47$, $p<.01)$, and the employees own perceived ability to perform improvement work $(\beta=.39-.45, p$ $<.01)$. Our interviews strongly supported that management support is crucial. All employees in all three companies noted that the support (or lack of support) from management influenced the work with improvement heavily. In one of the companies, the work with improvements had taken a halt due to that management constantly prioritized production before improvement leaving almost no room for improvement work. And if management shows that improvement work is secondary, this will likely influence the employees to pay less attention to it in the future, i.e., their intentions to engage will drop. The interviews also made it clear that that the experienced ability to work with improvements had strong influence on the intentions. The tools that the improvement consultant gave the employees were seen as important building blocks in the work with improvements. Those that were more skeptical towards improvement work also mentioned that they did not feel confident working with it and they preferred to work as they had done earlier.

Looking at the control variables, one of the firms (firm 1) has employees that have lower intentions. This is the largest company where the improvement project had been implemented the 
least at the time of the survey. Age is not significant for general improvement intentions, but for the more personal dimension - to learn from work - older employees tend to be more skeptical, in line with what we expected. Further, education has a weak positive effect in both models, which also is in line with expectations. The interviews indicated that younger, better-educated employees saw more benefits for themselves in working with improvement work. Older employees with less education agreed that the improvement work may be good for the company, but were skeptical about their personal benefits. We found it interesting that prior experience with the Black Belt consultant proved negative for intentions to learn from work. It seems that those that have been involved in pilot projects had been "burnt" from their experience. A plausible reason for this may be start-up problems of the first year of the project and that results have not met expectations of those who have participated. Another explanation could be that the respondents considered improvements a good thing, but much like house cleaning; it is good to have it done, but the actual work is better left to someone else. Since it is only significant for the "Intentions to learn from work" model, or the "selfish" model, this lends further support to both conclusions. Here, the interviews gave inconclusive results.

\section{Discussion and Limitations of Research}

In this section, we will first discuss the results. Then we will discuss the usefulness of TPB in improvement work research and practice. Finally, we will outline some limitations of the research and how this can be countered in future research.

If we first turn to our results for the case of the three SMEs that work with improvements together under the supervision of a shared Black Belt, clearly management is highly influential in getting employees to be committed to improvement work. The two categories in Ajzen's model that most easily can be linked to management (perceived behavioral control and subjective 
norms) also proved the most influential categories for employee's intentions regarding improvement work. The softer side of management, i.e., norms held by supervisors and upper management had the single strongest effect for intentions to engage in both general improvement work and intentions to learn from work. The norms perceived to be held by management were also singled out as vital in the interviews. The found coupling between management commitment and employee commitment is not new and the literature in quality management has for long emphasized the essential role that management involvement has for successful improvement work (e.g., Deming, 1986 p. 23-24, Garvin, 1986, Dow et al. 1999; Kathuria \& Davis, 2001; Klefsjö, Bergquist \& Edgeman, 2006). The harder side of management is linked to the employees' perceived behavioral control - i.e., the experienced competence of the employee - is the other strong precursor to intentions. As employees normally get much of their training on-thejob, experienced - and real - competence is largely determined by management actions. An employee can become a highly skilled worker through proper training and subsequent coaching. Likewise, without training and with poor coaching an employee can become a burden for the company. Thus, providing adequate training and coaching can be seen as another side of management support.

Still, the result that attitudes toward the improvement work did not have explanatory power by themselves was somewhat surprising. Even if attitudes by themselves are not enough to explain intentions (Fishbein and Ajzen, 1974), we expect attitudes to be strong predictors of intentions, since attitude is the variable that captures the individual's opinion of improvement work. Management aspects were found to override personal opinions in our case, but whether that holds generally outside the case setting is for future studies to explore. 
Even if the study is limited and does not monitor the actual behavior, we believe that the promising results demonstrate how TPB can measure employee commitment to (i.e., intentions to work with) improvement work. The results also suggest that TPB can enable a deeper understanding of many vital elements that are linked to improvement work commitment. The model worked well to explain our data, and the results obtained were also validated by follow-up interviews. Although we can conclude that the TPB model in this case was useful for determining the intentions to engage in the improvement work, as well as in pinpointing drivers and hindrances, we need also to recognize that intentions to engage is not enough. Measured general dispositions are not always good predictors of behaviors (see Ajzen \& Fishbein, 1977), since external factors may have larger influence on actions. However, the stronger the intentions to an action are, the larger the chances are that the intentions will result in the action (Ajzen, 1991).

The overall positive scores shown by the respondents when answering the Likert scale survey may partly be explained by a general tendency in surveys, where acquiescence is more common than dis-acquiescence (Harzing, 2006). This tendency has been found also for Swedish respondents, but the effect was less pronounced than in most other parts of the world in a study of 26 countries (ibid.). However, since the questionnaire was answered anonymously and analyzed by impartial researchers, it seems unlikely that the high response averages are a product of a willingness to appear positive towards management. Instead the employees had an opportunity to send a signal to management through the questionnaire if they had issues with the improvement work. Therefore, we believe that the scores represent fairly unbiased opinions about the variables under study.

The survey was designed to measure all the TPB constructs, except the actual behavior of the respondents. The reason to exclude behavior was taken for two reasons. The first reason was 
that we considered that the behavioral part was difficult to measure without going into detail about the work everyone had performed within the project. The second reason was that the management and improvement team considered the employees' intention to engage and the drivers for the intention even more important since many still had not had the chance to participate in the improvement work. However, in future studies it would be interesting to include actual behavior and have a stronger longitudinal dimension.

\section{Conclusions}

We conclude that Ajzen's theory of planned behavior is a promising framework to use for understanding and predicting improvement work projects. In the studied context - a network of SMEs working principally with Lean tools - visible management support (i.e., positive norms) and employee training and coaching (i.e., behavioral control) are vital to boost employees' intentions to engage in the improvement work. Many studies point to the advantages of having a successful implementation start, and reflecting on the higher intentions to engage found among the young and well educated, we suspect that it would be easier to start the improvement work in departments with younger, more highly educated people.

We also believe that the results add to the quality management literature. We provide results that indicate two important vehicles for management support to function as a tool for improvement work, indicating that management must ensure that the employees realize that the management supports the improvement work and they must make sure employees get the necessary training for their improvement project tasks. 


\section{References}

Abdullah, M. M. B., Uli, J. \& Tari, J. J. (2009). The relationship of performance with soft factors and quality improvement. Total Quality Management \& Business Excellence, 20(7). 735-748.

Ajzen, I., (1991). The theory of planned behavior. Organizational Behavior and Human Decision Processes, 5(2). 179-211.

Ajzen, I. \& Fishbein, M., (1977). Attitude-behavior relations: A theoretical analysis and review of empirical research. Psychological Bulletin, 84(5), 888-918. doi:10.1037//00332909.84.5.888

Ajzen, I. \& Fishbein, M. (1980). Understanding attitudes and predicting social behavior. Englewood Cliffs, NJ.

Aoki, K. (2008). Transferring Japanese kaizen activities to overseas plants in China. International Journal of Operation \& Production Management, 28(6), 518-539.

Bateman, N. (2005). Sustainability: the elusive element of process improvement. International Journal of Operation \& Production Management, 25(3), 261-276.

Conner, M. (2000). Temporal stability as a moderator of relationships in the Theory of planned behavior. British Journal of Social Psychology, 39(4), 469-493.

Das, A., Handfield, R. B., Calantone, R. J., \& Ghosh, S. (2000). A contingent view of quality management - the impact of international competition on quality. Decision Sciences, 31(3), 649-690. 
Dawkins, C. E., \& Frass, J. W. (2005). Decisions of union workers to participate in employee involvement: an application of the theory of planned behavior. Employee Relations, 27(5), 511-531.

Deming, W. E. (1986). Out of the crisis, Cambridge, MA: Massachusetts Institute of Technology.

Dow, D., Samson, D. \& Ford, S. (1999). Exploding the myth: Do all quality management practices contribute to superior quality performance?, Production and Operations Management, 8(1), 1-29..

Flynn, B. B., Shroeder, R. G., \& Sakakibara, S. (1995). The impact of quality management practices on performance and competitive advantage, Decision Sciences, 26(5), 659-691.

Garvin, D. A. (1986). Quality Problems, Policies and Attitudes in the United States and Japan: An Exploratory Study, Academy of Management Journal, 29(4), 653-673.

Harrison, D. A., Newman, D. A., \& Roth, P. L., (2006). How important are job attitude? Metaanalytic comparisons of integrative behavioral outcomes and time sequences, Academy of Management Journal, 49(2), 305-325.

Harter, J. K., Schmidt, F. L. \& Hayes, T. J. (2002). Business-unit-level relationship between employee satisfaction, employee engagement, and business outcomes: A meta-analysis, Journal of Applied Psychology, 87(2), 268-279.

Harzing, A.-W. (2006). Response styles in cross-national survey research - A 26-country study, International Journal of Cross Cultural Management, 6(2), 243-266.

Hendricks, K. B. \& Singhal, V. R. (2001). Firm characteristics, total quality management, and financial performance, Journal of Operations Management, 19(3), 269-285. 
Ho, D. C. K, Duffy, V. G., \& Shih, H. M. (2001). Total quality management: an empirical test for mediation effect, International Journal of Production Research, 39(3), 529-549. doi:10.1080/00207540010005709

Jackson, P. R. \& Martin, R. (1996). The impact of just-in-time on job content, employee attitudes and well-being: A longitudinal study, Ergonomics, 39(1), 1-16.

Jackson, P. R., Mullarkey, S. (2000). Lean production teams and health in garment manufacture, Journal of Occupational Health Psychology, 5(2), 231-245.

Jimmieson, N. L., Peach, M. \& White, K. M. (2008). Utilizing the theory of planned behavior to inform change management - An investigation of employee intentions to support organizational change, The Journal of Applied Behavioral Science, 44(2), 237-263.

Johansson, J. \& Abrahamsson, L. (2009). The good work - A Swedish trade union vision in the shadow of lean production, Applied Ergonomics, 30(1). 1-6.

Kathuria, R. \& Davis, E. B. (2001). Quality and work force management practices: The managerial performance implication. Production and Operations Management, 10(4), 460-477.

Kaynak, H. (2003). The relationship between TQM practices and their effects on firm performance. Journal of Operations Management, 21(4), 405-435.

Klefsjö, B., Bergquist, B. \& Edgeman, R. (2006). Six Sigma and Total Quality Management: Different Day, Same Soup? International Journal of Six Sigma and Competitive Advantage, 2(2), 162-178. 
Korunka, C., Scharitzer, D. \& Sainfort, F. (2003). Employee strain and job satisfaction related to an implementation of quality in a public service organization: a longitudinal study, Work \& Stress, 17(1), 52-72.

Landsbergis, P. A., Cahill, J., Schnall, P. (1999). The impact of lean production and related new systems of work organization on worker health, Journal of Occupational Health Psychology, 4(2), 108-130.

Lemak, D. \& Reed, R. (1997). Commitment to total quality management-Is there a relationship with firm performance?, Journal of Quality Management, 2(1), 67-86.

Nair, A. (2006). Meta-analysis of the relationship between quality management practices and firm performance—implications for quality management theory development, Journal of Operations Management, 24(4), 948-975.

Powell, T. C. (1995). Total quality management as a competitive advantage: a review and empirical study, Strategic Management Journal, 14(1), 15-37.

Prajogo, D. I., \& Sohal, A. S. (2006). The relationship between organization strategy, total quality management (TQM) and organization performance - the mediating role of TQM, European Journal of Operational Research, 168(1), 35-50.

Radnor Z. J., \& Boaden. R., (2004). Developing an understanding of corporate anorexia, International Journal of Operations and Production Management, 24(4), 424-440.

Samson, D., \& Terziovski, M. (1999). The relationship between total quality management practices and operational performance, Journal of Operations Management, 17(4), 393409. 
Shah, R. \& Ward, P. T. (2003). Lean manufacturing: context, practice bundles, and performance, Journal of Operations Management, 21(4), 768-784.

Sila, I. (2007). Examining the effects of contextual factors on TQM and performance through the lens of organizational theories: An empirical study, Journal of Operations Management, 25(1), 83-109.

Yeung, A. C., Cheng, T. C. E., \& Lai, K.-h. (2006). An operational and institutional perspective on Total quality management, Productions and operations management, 14(2), 156-170. 


\section{Appendix. Items and loadings for the scales used in the study}

\section{Personally, I would like to...}

Work more with improvement work

Get more opportunities to learn new things

Get more opportunities to learn from other's experiences

Gen. improvement

Work with tasks that leads to more contacts with new people

intention

Take more own initiatives

Share my knowledge to a greater extent

Cooperate more with others

Intention to learn

Get more opportunities to learn new things

from work

Change my work tasks more often 
Personally, I am good at...

Working with improvement work $\quad .845$

Ability IW

Learn new things

.873

Take own initiatives

.848

All Items measured on a Likert scale from 1 to 7. 